\title{
Determination of in vitro rumen digestibility and potential feed value of tiger nut varieties
}

\author{
T. Ayaşan" ${ }^{1 \#}$, E. Sucu', I. Ülger ${ }^{3}$, H. Hızlı ${ }^{4}$, P. Cubukcu \& B.D. Özcan ${ }^{5}$ \\ ${ }^{1}$ Osmaniye Korkut Ata University, Kadirli Academy of Applied Sciences, Osmaniye, Turkey \\ ${ }^{2}$ Uludağ University Agricultural Faculty, Department of Animal Science, Bursa, Turkey \\ ${ }^{3}$ Erciyes University Agricultural Faculty, Department of Animal Science, Kayseri, Turkey \\ ${ }^{4}$ East Mediterranean Agricultural Research Institute, Adana, Turkey \\ ${ }^{5}$ Cukurova University Agricultural Faculty Department of Animal Science, Adana, Turkey
}

(Submitted 22 April 2020; Accepted 28 July 2020; Published 14 November 2020)

\begin{abstract}
Copyright resides with the authors in terms of the Creative Commons Attribution 4.0 South African Licence.
See: http://creativecommons.org/licenses/by/4.0/za

Condition of use: The user may copy, distribute, transmit and adapt the work, but must recognise the authors and the South African Journal of Animal Science.
\end{abstract}

\begin{abstract}
Tiger nut (Cyperus esculentus L.), or chufa, is a plant that is found in nature and is cultivated for its edible tubers. The purpose of this study was to determine the chemical composition, nutritive value, and in vitro digestibility of three tiger nut varieties using the in vitro gas production technique. These varieties were Sarışeker (yellow), Introduction 1, and Balyumru (brown). Rumen fluid was obtained from two cannulated Holstein animals. Time-dependent in vitro gas production was monitored at 3, 6, 9, 12, 24, 48, 72, and 96 hours of incubation. The varieties differed in dry matter (DM), crude ash (CA), ether extract (EE), neutral detergent fibre (NDF), and nonfibre carbohydrate (NFC) content $(P<0.05)$. They also differed in the instantaneous volume of gas produced and in time-dependent gas production. Balyumru produced more gas at the onset of incubation than Introduction 1 and Sarışeker. However, over time, the gas produced by digestion of Introduction 1 exceeded the other two varieties. The amounts of gas produced at each time-point were intercorrelated. It is recommended that these results should lead to further evaluation in in vivo studies.
\end{abstract}

Keywords: chemical composition, energy content, in vitro gas production

\#Corresponding author: tayasan@gmail.com

\section{Introduction}

Farmers that are engaged in stockbreeding in developing countries face problems in the dry season, which include feed shortages, increased feed prices, and climate change. These challenges also affect the quality and quantity of animal protein available for human consumption. To overcome them, it is essential to focus on the use of lesser-known non-traditional feed ingredients such as tiger nuts (Cyperus esculentus $L$.) in animal nutrition (Belewu et al., 2007; Anonymous 2009a; 2009b; Agbabiaka et al., 2013; Suleiman et al., 2018).

Tiger nut (Cyperus esculentus L.) or chufa is a plant that is found in nature and is cultivated for its edible tubers, mostly in tropical and temperate regions. Tiger nut tubers may be consumed raw, processed as flour, and used in animal feed production. In addition, they are utilized in the pharmaceutical, cosmetics and perfumery industries (Nazlican, 2007). High-quality biofuel is obtained from tiger nut oil (Bilgili et al., 2018), which is good for human and animal health because it contains $18 \%$ saturated fatty acids (palmitic and stearic acids) and $82 \%$ unsaturated fatty acids (oleic and linoleic acids) (Zhang et al., 1996). Since tiger nuts do not contain gluten and cholesterol, they are considered a digestive tonic, and thus relieve bloating. Besides, their sodium content is low (Martinez, 2003).

To date, information on the potential use of tiger nuts in ruminant livestock nutrition has been limited. Previous studies focused on its use in feeding poultry, pigs (Ukpabi et al., 2019) and fish. For example, Bamgbose et al. (2003) reported that using 33.3\% tiger nuts instead of corn in rooster rations reduced feed costs significantly without affecting carcass parameters. Onunkwo and Ugwuene (2015) replaced $0 \%, 25 \%$, $50 \%$, and $75 \%$ corn with tiger nut meal in rations for Japanese quail. After 49 days, they reported that up to $50 \%$ of the corn could be replaced with tiger nut meal without reducing the growth of the birds. Similar 
findings were obtained by Agbabiaka et al. (2013) and Obidinma (2009), who reported that tiger nuts could replace $50 \%$ of corn in broiler rations. But the use of tiger nuts in feeding ruminant animals was evaluated only by Belewu et al. (2007), and that was carried out on goats. Therefore, in this study, the nutrient content, nutritive value, and digestibility in cattle of three tiger nut varieties grown in Turkey were examined with the in vitro gas production technique.

\section{Materials and methods}

The experiment was conducted at EMARI (36 $51^{\prime} 18^{\prime \prime}$ N 35 $\left.20^{\prime} 49^{\prime \prime} \mathrm{E}\right)$ in Adana Province in Turkey. The tiger nuts were grown at the institute and were collected in three replicates to represent all the samples. The dry feed samples were first ground in a mill with a sieve diameter of $1 \mathrm{~mm}$ and then used for the analyses. To determine the dry matter (DM) content, the ground samples were kept in an oven at $70^{\circ} \mathrm{C}$ for 24 hours and the differences between the weights before and after baking were computed and expressed in DM\%.

Dry matter, CA, CP, and EE were analysed according to the methods described by AOAC (1996). Acid detergent fibe (ADF) and NDF were analysed by the method described by Van Soest et al. (1991). Crude cellulose (CC) was determined Pinkerton's (2005) method. Hemicellulose (HC) was calculated with equations by Tekce and Gül (2014). In computing the non-structural carbohydrate (NFC) values, this equation by Weiss et al. (1992) was used:

$$
N F C \%=100-(N D F \%+C P \%+E E \%+C A \%)
$$

Total digestibility nutrients, digestible energy (DE), metabolizable energy (ME) and net energy lactation (NEL) were calculated using these formulas (MAFF, 1984):

$$
\begin{gathered}
T D N(\%)=27.66 \times M E(M c a l / k g D M) \\
D E(M c a l / k g D M)=0.04409 \times T D N(\%) \\
M E(M c a l / k g D M)=\left[3227-\frac{\{35.85 \times A D F(\%)+33.46 \times C P(\%)-35.85 \times C A(\%)\}}{1000}\right. \\
N E L(\text { Mcal } / k g D M)=\{0.0245 \times T D N(\%)\}-0.12
\end{gathered}
$$

To determine the nutrient digestibility of tiger nut varieties through in vitro gas production technique, two Holstein cattle were used, weighing approximately $575 \mathrm{~kg}$, and fitted with rumen cannulas. The experimental animals were housed at Bursa Uludağ University Veterinary Faculty Application and Research Centre. They were fed in two meals, morning and evening, with a mixture of $60 \%$ corn silage and $40 \%$ concentrate. The animals were provided continuously with clean water.

In vitro gas production from digestion of tiger nuts was determined using the gas production technique (Menke \& Steingass,1988) with $100 \mathrm{~mL}$ glass syringes (Model Fortuna, Häberle Labortechnik, LonseeEttlenschie $\beta$, Germany). Rumen liquid was collected just before the morning feeding and brought to the laboratory in a vacuum flask. It was filtered through three layers of cheesecloth. Approximately $200 \mathrm{mg}$ of a feed sample was weighed and combined with $40 \mathrm{ml}$ of an incubation medium in three replicate syringes. In addition to the rumen fluid, the incubation medium consisted of $620 \mathrm{ml}$ pure water, $310 \mathrm{ml}$ macro element solution, $0.16 \mathrm{ml}$ trace element solution, $310 \mathrm{ml}$ buffer solution and $1.6 \mathrm{ml}$ resazurin and reduction solutions. After being prepared for digestion the syringes were maintained in a water bath at $39^{\circ} \mathrm{C}$.

The volume of the gas formed in the syringes was recorded after $3,6,12,24,48,72$, and 96 hours of incubation. The gas production data were modelled with an exponential equation (Ørskov \& McDonald, 1979):

$$
G P=a+b\left(1-e^{-c t}\right)
$$

using the NeWay computer program (Chen, 1994) in which:

$G P=$ time-dependent $(\mathrm{t})$ gas production from the substrate $(\mathrm{mL})$

$a=$ instantaneous volume of the gas produced as the feed is placed in the artificial rumen $(\mathrm{mL})$

$b=$ time-dependent volume of the gas formed $(\mathrm{mL})$

$a+b=$ total (potential) gas production $(\mathrm{mL})$

$c=$ gas production rate constant $\left(\right.$ hour $^{-1}$ or $\%$ )

$t=$ time (hour) 
Analysis of variance procedures (SPSS Inc., Chicago, Illinois, USA) were used to test differences in digestibility and parameter estimates from the gas production curve among the tiger nut varieties after 3,6 , $12,24,48,72$, and 96 hours of in vitro digestion. Tukey's multiple comparison test was used to assess differences between varieties. Correlations between digestibility and the parameter estimates for the gas production curves at the 3rd, 6th, 12th, 24th, 72nd, and 96th hour of incubation were calculated as a measure of their relationship.

\section{Results and Discussion}

Differences in DM, CA and EE contents between varieties were statistically significant. The CP contents of these varieties were not detected as being different $(P>0.05)$. In fibre constituents, only the NDF content was found to vary. The more rapidly degradable NFC fraction also differed among varieties, and Sarışeker had with a markedly lower value than Introduction 1 and Balyumru. Values for the nutrient contents of the three varieties of tiger nuts are given in Table 1.

Table 1 Nutritional content of three tiger nut varieties, as a percentage of dry matter

\begin{tabular}{|c|c|c|c|c|c|}
\hline \multirow{2}{*}{ Nutrient, \% } & \multicolumn{3}{|c|}{ Varieties } & \multirow{2}{*}{ SE } & \multirow{2}{*}{$P$-value } \\
\hline & Sarışeker & Introduction 1 & Balyumru & & \\
\hline Dry matter & $94.62^{\mathrm{a}}$ & $93.86^{b}$ & $93.75^{b}$ & 0.172 & $<0.001$ \\
\hline Crude ash & $2.65^{\mathrm{a}}$ & $2.52^{\mathrm{b}}$ & $2.42^{\mathrm{c}}$ & 0.044 & 0.005 \\
\hline Crude protein & $4.45^{\mathrm{a}}$ & $4.41^{\mathrm{a}}$ & $4.32^{\mathrm{a}}$ & 0.127 & 0.942 \\
\hline Ether extract & $28.43^{\mathrm{a}}$ & $25.84^{b}$ & $20.28^{c}$ & 1.523 & $<0.001$ \\
\hline Acid detergent fibre & $14.91^{\mathrm{a}}$ & $14.01^{\mathrm{a}}$ & $16.21^{\mathrm{a}}$ & 0.484 & 0.168 \\
\hline Neutral detergent fibre & $23.86^{b}$ & $21.72^{\mathrm{c}}$ & $26.51^{\mathrm{a}}$ & 0.882 & 0.001 \\
\hline Acid detergent lignin & $5.64^{\mathrm{a}}$ & $5.77^{\mathrm{a}}$ & $5.74^{\mathrm{a}}$ & 0.140 & 0.960 \\
\hline Crude cellulose & $9.26^{\mathrm{a}}$ & $8.24^{\mathrm{a}}$ & $10.47^{\mathrm{a}}$ & 0.516 & 0.229 \\
\hline Hemi cellulose & $8.94^{\mathrm{a}}$ & $7.71^{\mathrm{a}}$ & $10.30^{\mathrm{a}}$ & 0.537 & 0.103 \\
\hline Non-structural carbohydrate & $40.61^{b}$ & $45.51^{\mathrm{a}}$ & $46.47^{\mathrm{a}}$ & 1.152 & 0.001 \\
\hline
\end{tabular}

${ }^{a, b, c}$ Within a row values with a common superscript were not different at $P=0.05$

The DM content of tiger nut tubers for varieties in Spain ranged from $91.3 \%$ to $92.9 \%$ and from $93.1 \%$ to $93.4 \%$ for the varieties in Turkey (Thomas, 2014). Aduwamai et al. (2018) reported that the DM contents of unprocessed, soaked, and roasted tiger nuts were $90.63 \%, 90.63 \%$, and $93.67 \%$, respectively, and the effect of processing techniques on DM was statistically significant. Emurotu (2017) stated that DM content in tiger nuts varied and was $88 \%$ in yellow tiger nuts and $89.98 \%$ in brown tiger nuts. Bobreneva \& Baioumy (2018) found the DM content of tiger nuts was $91.70 \%$, whereas Madaki et al. (2018) stated that the DM contents of processed and unprocessed tiger nuts were $92.11 \%$ and $90.33 \%$, respectively. These values were lower than the DM values that the authors found in the current study because of the varieties, the climate and soil structure of the region, and the processing techniques.

Tiger nut lines grown in the Çukurova region of Adana, southern Turkey, contained an average of 93.28\% DM, 24.5\% EE, 25.68\% starch, 1.42\% CA, 5.05\% CP, and 8.91\% CC. Özcan et al. (2010) found that the CP, EE, CC, and CA levels of tiger nut tubers were $8.11 \%, 21.60 \%, 22.13 \%$, and $2.34 \%$, respectively. The CP content found by Özcan et al. (2010) was substantially higher than the CP levels that were observed in this study. Gambo and Da'u (2014) stated that the CP content of tiger nuts varied based on strain and drying, and that the CP content of yellow tiger nuts (7.15\%) was lower than that of brown tiger nuts $(9.70 \%)$. Asante et al. (2014) stated that the CP content of varieties ranged between $4.62 \%$ and $5.46 \%$ on average. Bado et al. (2015) stated that the CP content of tiger nuts varied between 3.30 and $4.33 \mathrm{~g} / 100 \mathrm{~g}$, a result that is more similar to the present findings. The variance observed in the CP results of tiger nuts in several studies may stem from the strains or lines, the regions in which the crop was grown, analysis methods, processing techniques, and harvest times.

Asante et al. (2014) found that the fat content varied significantly among varieties from $19.27 \%$ to $21.92 \%$, values that are most similar to the EE content of Balyumru in the present study. Bado et al. (2015) 
reported that the EE content of tiger nut tubers varied between 24.91 and $28.94 \mathrm{~g} / 100 \mathrm{~g}$, results that are more similar to the present findings for Sarışeker and Introduction 1. Gambo and Da'u (2014) reported that the EE content in tiger nuts varied depending on strain and drying, and ranged between $32.13 \%$ and $35.43 \%$. Thomas (2014) asserted that the EE content was between $23 \%$ and $28.3 \%$. Achoribo and Ong (2017) stated that it was 30\%. As Ezeh et al. (2014) reported, the variations in tiger nut oil content resulted from the origin of the tuber, region, genetic structure, variety, and age of the tissue. Emurotu (2017) found the EE content in tiger nuts ranged from $21.9 \%$ to $23.1 \%$ with an average value of $22.45 \%$. Madaki et al. (2018) stated that the EE content of processed and unprocessed tiger nuts varied between $25.53 \%$ and $28.61 \%$. Oleic acid, palmitic acid, and linoleic acid are major contributors to the oil extracted from tiger nuts (Coşkuner et al., 2002). Thus, it can be concluded that tiger nuts are an energy dense feedstuff. However, high level of fats in the diet could prove toxic to rumen microbes and affect fibre digestibility (Behan et al., 2019). Thus the fat content of tiger nuts should be considered in formulating rations for ruminant animals when tiger nuts are fed.

The average ADF content, an indicator of digestibility of roughages (Van Soest, 1967), was $15.04 \%$ in this study. Balyumru had the highest ADF content with $16.21 \%$. When the NDF contents were examined, the lowest NDF was found in Introduction 1 with $21.72 \%$, whereas the highest NDF content was observed in Balyumru with $26.51 \%$. The neutral detergent fibre content is closely related to the feed consumption. The recommended ADF and NDF contents in the total ration for dairy cattle are $23 \%$ and $36-38 \%$, respectively. The ideal NDF content from the roughage is accepted to be $27-28 \%$ (NRC, 2001).

Asante et al. (2014) reported that the CC of several varieties ranged between $7.42 \%$ and $11.8 \%$ and between $7.5 \%$ and $13.5 \%$. Thomas (2014) stated that the CC for the tiger nut tubers of the varieties in Spain ranged between $9.8 \%$ and $11.0 \%$ and that it was $8.7 \%$ for the varieties in Turkey. Emurotu (2017) found the CC content in tiger nuts was between 23.3 and $26.0 \%$ with an average of $24.7 \%$, while Bobreneva and Baioumy (2018) found it was $15.37 \%$, and Madaki et al. (2018) observed values between $22.34 \%$ and $24.94 \%$. Based on the results pertaining to NDF, ADF, and CC ruminant animals fed tiger nut tubers will likely require supplementation with other sources of fibre.

Non-fibre carbohydrate (NFC) content is calculated through a formula that uses NDF, CP, EE, and CA (Table 4). A statistically significant difference was found between the varieties in terms of NFC, and the average NFC content was $44.20 \%$. The total digestible nutrients ranged from $71.59 \%$ to $73.78 \%$, revealing a statistically insignificant difference (Table 4) $(P>0.05)$.

Beyond the initial gas production recorded at three hours of incubation, no further differences were observed until the 24th hour (Table 2). The highest gas production at that point was observed in Introduction 1 , whereas Sarışeker and Balyumru had produced significantly less gas at that time. This pattern of Introduction 1 producing more gas than the other two varieties was maintained through 96 hours. For all three varieties, the gas production reached stasis at approximately $24 \mathrm{~h}$ which might be interpreted as implying an impairment of microbial digestion by the high fat content of tiger nuts.

Table 2 In vitro gas production of three tiger nut varieties as a function of incubation time

\begin{tabular}{lccccccc}
\hline Varieties & $3 \mathrm{~h}$ & $6 \mathrm{~h}$ & $12 \mathrm{~h}$ & $24 \mathrm{~h}$ & $48 \mathrm{~h}$ & $72 \mathrm{~h}$ & $96 \mathrm{~h}$ \\
\hline Introduction 1 & $16.71^{\mathrm{a}}$ & $22.43^{\mathrm{a}}$ & $33.18^{\mathrm{a}}$ & $42.76^{\mathrm{a}}$ & $46.05^{\mathrm{a}}$ & $48.77^{\mathrm{a}}$ & $56.44^{\mathrm{a}}$ \\
Sarışeker & $11.38^{\mathrm{b}}$ & $15.43^{\mathrm{a}}$ & $24.85^{\mathrm{a}}$ & $34.93^{\mathrm{b}}$ & $35.68^{\mathrm{b}}$ & $36.44^{\mathrm{b}}$ & $36.60^{\mathrm{b}}$ \\
Balyumru & $12.04^{\mathrm{b}}$ & $16.76^{\mathrm{a}}$ & $26.85^{\mathrm{a}}$ & $34.10^{\mathrm{b}}$ & $35.52^{\mathrm{b}}$ & $37.27^{\mathrm{b}}$ & $39.10^{\mathrm{b}}$ \\
$\mathrm{SE}$ & 1.07 & 1.49 & 1.80 & 1.72 & 2.07 & 2.34 & 3.47 \\
$P$-value & 0.059 & 0.110 & 0.134 & 0.044 & 0.025 & 0.022 & 0.007 \\
\hline
\end{tabular}

${ }^{\mathrm{a}, \mathrm{b}}$ Within a column values with a common superscript were not different at $P=0.05$

Initial gas production was higher for Balyumru than for Introduction 1 and Sarışeker (Table 3). However, over time the gas produced from Introduction 1 exceeded that produced by the other two varieties. The rate parameter did not differ. Thus, the net effect of less gas being produced by Sarışeker was an indication of a possible lower degree of ruminal fermentation.

Although there were significant differences among the tiger nut varieties, the predicted energy content for ruminant livestock, whether measured as total digestible nutrients (TDN), DE, ME, or NEL, did not differ significantly in in vitro gas production (Table 4). This was contrary to the expectation based on Menke and 
Steingass (1988) of a strong correlation between ME and 24 hours in vitro gas production. The metabolizable energy content of tiger nuts differed, depending on the variety, and ranged from 4.59 to 4.71 Mcal/kg (Gambo \& Da'u, 2014).

Table 3 Parameter estimates for exponential equation ${ }^{1}$ describing kinetics of in vitro gas production of three varieties of tiger nuts through 96 hours of incubation

\begin{tabular}{llclc}
\hline Varieties & $a$ & $b$ & $c$ & $a+b$ \\
\hline Introduction 1 & $2.5^{\mathrm{b}}$ & $44.87^{\mathrm{a}}$ & $0.10^{\mathrm{a}}$ & $47.37^{\mathrm{a}}$ \\
Sarışeker & $2.48^{\mathrm{b}}$ & $34.92^{\mathrm{b}}$ & $0.09^{\mathrm{a}}$ & $37.40^{\mathrm{b}}$ \\
Balyumru & $3.70^{\mathrm{a}}$ & $39.51^{\mathrm{b}}$ & $0.08^{\mathrm{a}}$ & $43.21^{\mathrm{a}}$ \\
$\mathrm{SE}$ & 0.22 & 1.60 & 0.01 & 1.61 \\
$P$-value & 0.004 & 0.007 & 0.235 & 0.007 \\
\hline
\end{tabular}

ØØrskov \& McDonald (1979)

a,b Within a column values with a common superscript were not different at $P=0.05$

$a$ : instantaneous gas production $(\mathrm{mL}), b$ : time-dependent volume of gas produced $(\mathrm{mL}), c$ : gas production rate constant

Table 4 Estimated total digestible nutrients, digestible energy, metabolizable energy and net energy for lactation contents of three tiger nut varieties

\begin{tabular}{lcccc}
\hline Varieties & TDN, \% DM & DE, Mcal/Kg DM & ME, Mcal/Kg DM & NEL, Mcal/Kg DM \\
\hline Sarışeker & $72.98^{\mathrm{a}}$ & $3.22^{\mathrm{a}}$ & $2.64^{\mathrm{a}}$ & $1.67^{\mathrm{a}}$ \\
Introduction 1 & $73.78^{\mathrm{a}}$ & $3.25^{\mathrm{a}}$ & $2.67^{\mathrm{a}}$ & $1.69^{\mathrm{a}}$ \\
Balyumru & $71.59^{\mathrm{a}}$ & $3.16^{\mathrm{a}}$ & $2.59^{\mathrm{a}}$ & $1.63^{\mathrm{a}}$ \\
SE & 0.468 & 0.020 & 0.017 & 0.011 \\
$P$-value & 0.077 & 0.123 & 0.123 & 0.123 \\
\hline
\end{tabular}

${ }^{a}$ Within a column values with a common superscript letter did not differ at $P=0.05$

TDN: total digestible nutrients, DE: digestible energy, ME: metabolizable energy, NEL: net energy for lactation, DM: dry matter

The amounts of gas produced by in vitro incubation of tiger nuts were highly correlated $(P>0.85)$ across time (Table 5). Thus, a 96 hours of in vitro incubation may have been longer than necessary.

Table 5 Estimates of Pearson correlation among quantities of gas produced over time from in vitro incubation of tiger nuts

\begin{tabular}{|c|c|c|c|c|c|c|}
\hline Time & $6 \mathrm{~h}$ & $12 \mathrm{~h}$ & $24 \mathrm{~h}$ & $48 \mathrm{~h}$ & $72 \mathrm{~h}$ & $96 \mathrm{~h}$ \\
\hline $3 \mathrm{~h}$ & $.966 *$ & $.937^{* *}$ & $.841^{* *}$ & $.911^{* *}$ & $.922^{* *}$ & $.868^{* *}$ \\
\hline $6 \mathrm{~h}$ & & $.991^{* *}$ & $.846^{* *}$ & $.895^{* *}$ & $.901^{* *}$ & $.876^{* *}$ \\
\hline $12 \mathrm{~h}$ & & & $.860^{* *}$ & $.894^{* *}$ & $.882^{* * *}$ & $.859^{* *}$ \\
\hline $24 \mathrm{~h}$ & & & & $.980^{* *}$ & $.919^{* *}$ & $.893^{* *}$ \\
\hline $48 \mathrm{~h}$ & & & & & $.971^{* *}$ & $.926^{* *}$ \\
\hline $72 \mathrm{~h}$ & & & & & & $.964^{* *}$ \\
\hline
\end{tabular}

${ }^{* *} P<0.01$ 
In examining the correlations among parameter estimates (Ørskov \& McDonald, 1979), the large correlation (0.991) between estimates for the volume of gas formed over time and the total amount of gas produced indicated that the instantaneous gas production was negligible. It seems that the time-dependent volume of the gas explained virtually all of the total gas production. None of the other correlations among the estimated parameters were significant $(P>0.05)$, although the correlation between the instantaneous volume of gas produced and the gas production rate constant $(-0.355)$ was of a magnitude to merit further study.

\section{Conclusion}

Tiger nuts may be regarded as an energy feed owing to their high fat content and abundance of carbohydrates. Thus, tiger nuts may have potential as an inexpensive source of energy for feeding ruminant animals. If tiger nuts are used in livestock feeding, this may reduce the competition between humans and animals for maize and other cereals. The use of tiger nuts in the diets for ruminant animals needs further study. The results from this research should be supported by an in vivo feeding and digestion trials.

\section{Authors' Contributions}

TA contributed to the project idea, design and execution of the study. ES, IÜ, HH, PÇ conducted the laboratory analyses. TA, ES and BDÖ supervised the experiment and wrote the manuscript.

\section{Conflict of Interest Declaration}

The authors declare that that there are no competing interests.

\section{References}

Achoribo, E.S. \& Ong, M.T., 2017. Tiger nut (Cyperus esculentus): Source of natural anti-cancer drug? Brief review of existing literature. EuroMediterranean Biomedical J. 12(19), 091-094.

Aduwamai, U.H., John, U.I., Aminu, A. \& Isaac, U.K., 2018. Influence of different processing methods on proximate and anti-nutritional value of tiger nuts (Cyperus esculentus L.). GSC Biological and Pharmaceutical Sciences 03(03), 029-034.

Agbabiaka, L.A., Madubuike, F.N., Ekenyem, B.U. \& Esonu, B.O., 2013. Effect of feeding different levels of tiger nut (Cyperus esculentus) meal on growth of broiler chicks. Am. J. Expt. Agric. 3(4), 996-1004.

Anonymous., 2019a. Tigernuts/chufas. https://www.tigernuts.com/pdf/tigernuts.profile.pdf

Anonymous., 2019b. Yer Bademi. https://www.tunaproject.com.tr/urunler-321269/tarimsal-urunler/superfoods/detay/417425/yer-bademi--tiger-nuts-

Asante, F.A., Oduro, I., Ellis, W.O. \& Saalia, F.K., 2014. Effect of planting period and site on the chemical composition and milk acceptability of (Cyperus Esculentus L.) tubers in Ghana. American Journal of Food and Nutrition 2(3),49-54.

Association of Official Analytical Chemists (AOAC)., 1996. Official methods of analysis. 15th edition. Washington DC, USA.

Bado, S., Bazongo, P., Son, G., Kyaw, M.T., Forster, B.P., Nielen, S., Lykke, A.M., Ouédraogo, A. \& Bassolé, I.H.N., 2015. Physicochemical characteristics and composition of three morphotypes of Cyperus esculentus tubers and tuber oils. J. Analytical Methods Chem. Article ID 67354. http://dx.doi.org/10.1155/2015/673547.

Bamgbose, A.M., Eruvbetine, D. \& Dada, W., 2003. Utilization of tigernut (Cyperus rotundus, L.) meal in diets for cockerel starters. Bioresource Tech. 89, 245-248.

Behan, A.A., Loh, T.C., Fakurazi, S., Kaka, U., Kaka, A. \& Samsudin, A.A., 2019. Effects of supplementation of rumen protected fats on rumen ecology and digestibility of nutrients in sheep. Animals (Basel), 9(7):400. doi:10.3390/ani9070400

Belewu, M.A., Orisameyiti, B.R. \& Ajibola, K.A., 2007. Effect of feeding graded levels of tigernut (cyperus esculentus) seed meal on the performance characteristics of West African dwarf goat. Pakistan J. Nutr. 6(6), 528-529.

Bilgili, M.E., Çubukcu, P. \& Vurarak, Y., 2018. Yerbademinin Tarımı ve Mekanizasyonunun Değerlendirilmesi. Uluslararası Doğu Akdeniz Tarımsal Araştırma Enstitüsü Dergisi. 1(2), $20-33$.

Bobreneva, I.V. \& Baioumy, A.A., 2018. Effect of using tiger nuts (Cyperus esculentus) on nutritional and organoleptic characteristics of beef burger. Biosci. Res. 15(3), 1424-1432.

Chen, X.B., 1994. Neway Excel. An Excel application program for processing feed degradability data. User manual. Int. Feed Resources Unit. Rowrett Research Institute, Scotland (unpublished).

Coşkuner, Y., Ercan, R., Karababa, E. \& Nazlıcan, A.N., 2002. Physical and chemical properties of chufa (Cyperus esculentus $L$ ) tubers grown in the Çukurova region of Turkey. J. Sci. Food Agric. 82(6), 625-631.

Emurotu, J.E., 2017. Comparison of the nutritive value of the yellow and brown varieties of tiger nut. IOSR J. Appl. Chem. 10(9), 29-32.

Ezeh, O., Gordon, M.H. \& Niranjan, K., 2014. Tiger nut oil (Cyperus esculentus L.): A review of its composition and physico-chemical properties. Eur. J. Lipid Sci. Tech. 116, 783-794.

Gambo, A. \& Da'u A., 2014. Tiger nut (Cyperus Esculentus): Composition, products, uses and health benefits - A review. Bayero J. Pure Appl. Sci. 7(1), 56-61.

Madaki, F.M., Kabiru, A.Y., Muhammad, H.L., Abubakar, A.N. \& Bello, A., 2018. Comparative nutritional compositions of raw and processed tiger nuts (Cyperus esculentus L.). IJABR. 9(2), 32-40.

MAFF., 1984. Energy allowances and feeding systems for ruminants. Her Majesty's Stationary Office London, UK. 
Mart'inez-Valls, J.F., 2003. Horchata y Salud: Posibles beneficios de la horchata de chufa en la prevencion de la arteriosclerosis. In: Jornada Chufa y 'Horchata: Tradicion y Salud, editor. Fundaci ' on Valenciana de Estudios ' Avanzados. Valencia, Spain: Conseller'ia de Agricultura, Pesca y Alimentacion. Pp. 87-94.

Menke, K.H. \& Steingass, H., 1988. Estimation of the energetic feed values obtained from chemical analysis and In vitro gas production using rumen liquid. Anim. Res. Dev. 28, 7-55.

Nazlıcan, A.N., 2007. Yağ, nişasta ve şeker üretiminde yeni bir alternatif: yerbademi. Agroskop Tarım Gıda Hayvancılık Dergisi. 1(1), 54-55.

National Research Council., 2001. Nutrient requirements of dairy cattle. Natl. Acad. Press, Washington DC.

Obidinma, V.N., 2009. Brewers spent grain as energy source in finisher broiler birds and laying hen production. Ph.D thesis, Department of Animal Science and Fisheries, Imo State University, Owerri, Nigeria.

Onunkwo, D.N. \& Ugwuene, M.C., 2015. Growth response of Japanese quails (Coturnix coturnix) fed varying levels of tiger nut (Cyperus esculentus L.) seed meal. International Journal of Livestock Research. 5(3), 35-41.

Ozcan, M.M., Gumuscu, A., Er, F., Arslan, D. \& Ozkalp, B., 2010. Chemical and fatty acid composition of Cyperus esculentus. Chemistry of Natural Compounds. 46(2), 276-277.

Ørskov, E.R. \& Mcdonald, I., 1979. The estimation of protein degradability in the rumen from incubation measurements weighed according to rate of passage. J. Agriculture Science 92, 499-503.

Pinkerton, B., 2005. Forage quality. Clemson University Cooperative Extension Service. Forage fact sheet 2.

Suleiman, M.S., Olajide, J.E., Omale, J.A., Abbah, O.C. \& Ejembi, D.O., 2018. Proximate composition, mineral and some vitamin contents of tigernut (Cyperus esculentus). Clin. Invest. 8(4),161-165.

Thomas, A.D., 2014. Physical, chemical and functional properties of tiger nuts (Cyperus esculentus) selected from Ghana, Cameroon and UK Market (Spain). University of Plymouth Research theses, doctoral thesis, P. 254.

Tekce, E. \& Gül, M., 2014. The importance of NDF and ADF in ruminant nutrition. Atatürk Üniversitesi Veteriner Bilimleri Dergisi 9(1), 63-73.

Ukpabi, U.H., Mbachu, C.L. \& Igboegwu, C.M., 2019. Growth performance, carcass and organ characteristics of grower pigs fed varying levels of tigernut (Cyperus esculentus L.) seed meal. Nigerian J. Anim. Sci. 21(1), 214-221.

Van Soest, P.J., 1967. Use of detergents in the analysis of fibrous feeds. Determination of plant cell wall constituents. J. Assoc. Official Analytical Chemists 50, 50-55.

Van Soest, P.J., Robertson, J.D. \& Lewis, B.A., 1991. Methods for dietary fibre, neutral detergent fibre and non-starch polysaccharides in relation to animal nutrition. J. Dairy Sci. 74,3583-3597.

Weiss, W.P., Conrad, H.R. \& St Pierre, N.R., 1992. A theoretically-based model for predicting total digestible, nutrient values of forages and concentrates. Anim. Feed Sci. Tech. 39(1-2), 95-110.

Zhang H.Y., Hanna M.A., Ali Y. \& Nan L., 1996. Yellow nutsedge (Cyperus esculentus L.) tuber oil as a fuel. Ind. Crop Prod. 5,177-181. 